\title{
A Novel Synthesis Method of Porous Calcium Silicate Hydrate Based on the Calcium Oxide/Polyethylene Glycol Composites
}

\author{
Wei Guan, Fangying Ji, Yong Cheng, Zhuoyao Fang, \\ Dexin Fang, Peng Yan, and Qingkong Chen \\ Key Laboratory of Three Gorges Reservoir Region's Eco-Environment, Ministry of Education, \\ Chongqing University, Chongqing 400045, China \\ Correspondence should be addressed to Fangying Ji; jfytougao@163.com
}

Received 9 August 2013; Revised 1 September 2013; Accepted 2 September 2013

Academic Editor: Fan Dong

Copyright (C) 2013 Wei Guan et al. This is an open access article distributed under the Creative Commons Attribution License, which permits unrestricted use, distribution, and reproduction in any medium, provided the original work is properly cited.

This paper proposed a novel method to prepare porous calcium silicate hydrate (CSH) based on the calcium oxide/polyethylene glycol $\left(\mathrm{CaO} / \mathrm{PEG}_{2000}\right)$ composites as the calcium materials. The porosity formation mechanism was revealed via $\mathrm{X}$-ray diffraction (XRD), field-emission scanning electron microscopy (FESEM), Brunauer-Emmett-Teller (BET), and Fourier transformed infrared spectroscopy (FT-IR). The reactivity of silica materials $\left(\mathrm{SiO}_{2}\right)$ enhanced by increasing $\mathrm{pH}$ value. $\mathrm{Ca}^{2+}$ could not sustain release from $\mathrm{CaO} / \mathrm{PEG}_{2000}$ and reacted with $\mathrm{SiO}_{3}{ }^{2-}$ caused by silica to form $\mathrm{CSH}$ until the hydrothermal temperature reached to $170^{\circ} \mathrm{C}$, avoiding the hardly dissolved intermediates formation efficiently. The as-prepared $\mathrm{CSH}$, due to the large specific surface areas, exhibited excellent release capability of $\mathrm{Ca}^{2+}$ and $\mathrm{OH}^{-}$. This porous CSH has potential application in reducing the negative environmental effects of continual natural phosphate resource depletion.

\section{Introduction}

Phosphate, as an irreplaceable and nonrenewable resource, has an important contribution to industry and agriculture [14]. But this precious resource will be exhausted as a result of increased consumption in the near future [5-8]. The sustainable utilization of phosphate has become a severe challenge for human beings. Calcium silicate hydrate, due to the unique release capability of $\mathrm{Ca}^{2+}$ and $\mathrm{OH}^{-}$, has caused international extensive concern in the field of "recovery of phosphate from wastewater" [9-14]. This is because the released $\mathrm{Ca}^{2+}$ and $\mathrm{OH}^{-}$can react with the phosphate ions to form hydroxyapatite (HAP) on the surface of $\mathrm{CSH}$ when the concentration of these ions reached to the supersaturated conditions [1517]. Therefore, the release capability of $\mathrm{Ca}^{2+}$ and $\mathrm{OH}^{-}$of $\mathrm{CSH}$ plays a key role in the field of phosphate recovery.

It is worthy to notice that the release capability is related to the specific surface area $\left(S_{\mathrm{BET}}\right)$ and pore structure. Large $S_{\mathrm{BET}}$ and porous structures are beneficial to enhance the solubility of CSH $[18,19]$. The current CSH samples were prepared by dynamic hydrothermal synthesis using $\mathrm{CaO}$ materials and $\mathrm{SiO}_{2}$ materials [20-23]. However, there two critical problems that affect the solubility of CSH. On the one hand, the reactivity of $\mathrm{SiO}_{2}$ was too poor to participate in the formation of CSH. The residual $\mathrm{SiO}_{2}$ precipitated on the surface of $\mathrm{CSH}$ is easy to block the pore structure and decrease the solubility of CSH. According to the previous study, the proper temperature to synthesize $\mathrm{CSH}$ was $170^{\circ} \mathrm{C}[18,19]$. However, there were abundant hard dissolve intermediates such as calcium silicate, formed during the heating process. These intermediates coated on the surface of $\mathrm{CSH}$ and affected the solubility of CSH $[24,25]$. Therefore, enhancing the reactivity of $\mathrm{SiO}_{2}$ materials and avoiding the formation of intermediates are the critical factors for the formation of $\mathrm{CSH}$ with porous structure.

A synthesis strategy based on calcium oxide/polyethylene glycol $\left(\mathrm{CaO} / \mathrm{PEG}_{2000}\right)$ composites was developed for the formation of porous CSH. Under the dynamic hydrothermal condition, massive $\mathrm{SiO}_{3}{ }^{2-}$ (released from the $\mathrm{SiO}_{2}$ materials due to the increased $\mathrm{pH}$ values) reacted with $\mathrm{Ca}^{2+}$ (sustained released from $\mathrm{CaO} / \mathrm{PEG}_{2000}$ composites) at a proper temperature to form CSH efficiently. Compared with previously reported synthesis methods, this new synthesis method 
TABLE 1: Chemical components of carbide residue.

\begin{tabular}{lcccccccccc}
\hline & \multicolumn{1}{c}{ Chemical composition (\%) } \\
& $\mathrm{CaO}$ & $\mathrm{SiO}_{2}$ & $\mathrm{Al}_{2} \mathrm{O}_{3}$ & $\mathrm{SO}_{2}$ & $\mathrm{MgO}$ & $\mathrm{Fe}_{2} \mathrm{O}_{3}$ & $\mathrm{SrO}$ & $\mathrm{NaOH}$ & $\mathrm{CuO}$ & $\mathrm{H}_{2} \mathrm{O}$ \\
\hline Carbide residue & 79.34 & 3.57 & 2.14 & 1.22 & 0.62 & 0.21 & 0.26 & - & - \\
Silica & 0.08 & 97.46 & 0.16 & 1.82 & - & 0.03 & - & 0.29 & 0.02 & 0.14 \\
\hline
\end{tabular}

herein avoided the formation of the hardly dissolved intermediates. Thus, the as-prepared $\mathrm{CSH}$ with porous structure exhibited excellent release capabilities of $\mathrm{Ca}^{2+}$ and $\mathrm{OH}^{-}$. In addition, a novel porosity formation mechanism was revealed in the present paper.

\section{Materials and Methods}

2.1. Raw Materials. The $\mathrm{CaO}$ material (carbide residue, content of $\mathrm{CaO}>75 \%$ ) and $\mathrm{SiO}_{2}$ material (Silica, content of $\mathrm{SiO}_{2}>98 \%$ ) were obtained from Chongqing Changshou Chemical Co. Ltd. $\mathrm{PEG}_{2000}$ (the chemical formula is $\left.\mathrm{HO}\left(\mathrm{CH}_{2} \mathrm{CH}_{2} \mathrm{O}\right)_{n} \mathrm{H}\right)$ and $\mathrm{NaOH}$ were obtained from Chengdu Kelong chemical Co. Ltd. The Chemical composition of the carbide residue and silica is presented in Table 1. The above materials and chemicals were placed into sealed bottles for storage.

2.2. Dynamic Hydrothermal Synthesis of Porous CSH. Prior to $\mathrm{CSH}$ synthesis, $\mathrm{PEG}_{2000}$ was put into $300 \mathrm{~mL}$ deionized water with strong stirring to obtain the PEG solution, and the mass fraction of $\mathrm{PEG}_{2000}$ was $2 \% \mathrm{w} / \mathrm{v}$. Subsequently, $6 \mathrm{mg}$ of carbide residue was added into the PEG solution with strong stirring and reacted $60 \mathrm{~min}$ at $80^{\circ} \mathrm{C}$. Then, the solid segments were centrifugal separated from the PEG solution and were dried at $105^{\circ} \mathrm{C}$ for $2 \mathrm{~h}$ to obtain the $\mathrm{CaO} / \mathrm{PEG}_{2000}$ composites.

Subsequently, $\mathrm{CaO} / \mathrm{PEG}_{2000}$ composites and $\mathrm{CaO}$ materials were mixed with $\mathrm{SiO}_{2}$ material to form a $300 \mathrm{~mL}$ slurry (liquid/solid mass ratio is $30 / 1$; Ca/Si molar ratio is $1.75 / 1$ ), respectively. $1 \mathrm{~mol} / \mathrm{L}$ of $\mathrm{NaOH}$ was used to maintain the $\mathrm{pH}$ values of the slurry at 13.0. Mixtures were agitated at $90 \mathrm{rpm}$, and the resulting slurry was put into a high-pressure kettle for hydrothermal synthesis at $170^{\circ} \mathrm{C}$ for $6 \mathrm{~h}$. The as-prepared $\mathrm{CSH}$ samples obtained from $\mathrm{CaO} / \mathrm{PEG}_{2000}$ composites and $\mathrm{CaO}$ materials were labeled as $\mathrm{CSH}\left(\mathrm{CaO} / \mathrm{PEG}_{2000}\right)$ and $\mathrm{CSH}$ $(\mathrm{CaO})$, respectively.

2.3. Dissolution Experiment. The release of $\mathrm{Ca}^{2+}$ and $\mathrm{OH}^{-}$ from CSH was investigated via a series of batch experiments. For each experiment, $1 \mathrm{~g}$ of $\mathrm{CSH}$ was poured into $1 \mathrm{~L}$ of deionized water in glass bottles, thus leading to a sample to solution ratio of $1 \mathrm{~g} / \mathrm{L}$. The bottles were then placed on an agitation table and mixed at $40 \mathrm{rpm}$ at $20^{\circ} \mathrm{C}$ for $5,10,15,20,40,60,80$, and $100 \mathrm{~min}$. The resulting $\mathrm{Ca}^{2+}$ concentration was determined using the EDTA coordination titration method (the relative derivation of data is $0.05 \%)$. Solution $\mathrm{pH}$ value was measured $( \pm 0.1)$ using precise $\mathrm{pH}$ paper $(\mathrm{pH} 7.0-10.0$, Sanai-si reagent Co., Ltd., Shanghai, China). The accuracy of $\mathrm{pH}$ measurement is 0.1 .
2.4. Experiments on Phosphate Recovery from Synthetic Solutions. Phosphate recovery property of the as-synthesized samples were investigated in a series of batch experiments. The $\mathrm{pH}$ values of phosphate-content solution were in the range of 7.0-7.5 before the CSH samples was added into this solution. For each one, one glass bottle containing $1 \mathrm{~L}$ of a synthetic solution with initial phosphate concentration $(100 \mathrm{mg} / \mathrm{L})$ was prepared. Then $1 \mathrm{~g}$ of synthesized sample was put into this bottle, thus leading to a sample-to-solution ratio of $1 \mathrm{~g} / \mathrm{L}$. The bottle was placed on an agitation table and shaken at $40 \mathrm{r} / \mathrm{min}$ under given temperature conditions $\left(20^{\circ} \mathrm{C}\right)$ for $60 \mathrm{~min}$. The solid samples after reaction were then separated from the removed synthetic solution, and were added again to synthetic solution with initial phosphate concentration of $100 \mathrm{mg} / \mathrm{L}$. This experiment was repeated for six times until the phosphate concentration was kept unchanged with the addition of samples. The content of phosphate in the recovered products was identified with atomic absorption spectrophotometry (Atomic Absorption Spectrometer, AA800, USA).

2.5. Characterization Instruments. The phase component and crystal structure of CSH are determined using X-ray diffraction with $\mathrm{Cu} K_{\alpha}$ radiation (XRD, model XD-2 instrument, China). The morphology was observed by fieldemission scanning electron microscopy (FESEM, IUE, Hitachi, Japan) and transmission electron microscope (TEM, JEOL JEM-2010, Japan). The $S_{\text {BET }}$ and pore structure was investigated using adsorption-desorption measurements. Nitrogen adsorption-desorption isotherms were obtained on a nitrogen adsorption apparatus (ASAP-2010, USA). The microstructures are evaluated by Fourier transformed infrared spectroscopy (FT-IR, IR Prestige-21FT-infrared spectrometer, Shimadzu, Japan).

\section{Results and Discussion}

3.1. The Effect of $\mathrm{pH}$ on the Reactivity of $\mathrm{SiO}_{2}$. In the water solution, the main existence forms of silicon are different with the changes of $\mathrm{pH}$ values. Silicon exists in the form of $\mathrm{SiO}_{3}{ }^{2-}$ when the $\mathrm{pH}$ value is over 13.0 [26-28]. This result can be verified according to the fraction formula of $\mathrm{H}_{2} \mathrm{SiO}_{3}, \mathrm{HSiO}_{3}{ }^{-}$and $\mathrm{SiO}_{3}{ }^{2-}$ under the given $\mathrm{pH}$ value as follows:

$$
\begin{gathered}
\delta_{\mathrm{H}_{2} \mathrm{SiO}_{3}}=\frac{\left[\mathrm{H}^{+}\right]^{2}}{\left[\mathrm{H}^{+}\right]+K_{\alpha 1}\left[\mathrm{H}^{+}\right]+K_{\alpha 1} K_{\alpha 2}}, \\
\delta_{\mathrm{HSiO}_{3}{ }^{-}}=\frac{K_{\alpha 1}\left[\mathrm{H}^{+}\right]}{\left[\mathrm{H}^{+}\right]^{2}+K_{\alpha 1}\left[\mathrm{H}^{+}\right]+K_{\alpha 1} K_{\alpha 2}},
\end{gathered}
$$




$$
\delta_{\mathrm{SiO}_{3}^{2-}}=\frac{K_{\alpha 1} K_{\alpha 2}}{\left[\mathrm{H}^{+}\right]^{2}+K_{\alpha 1}\left[\mathrm{H}^{+}\right]+K_{\alpha 1} K_{\alpha 2}}
$$

where $\left[\mathrm{H}^{+}\right]$is the concentration of hydrogen ions and $K_{\alpha 1}$ and $K_{\alpha 2}$ are the first and second dissociation constants, respectively. When $\mathrm{pH}=12.0$, the distribution coefficients of $\mathrm{H}_{2} \mathrm{SiO}_{3}, \mathrm{HSiO}_{3}{ }^{-}$, and $\mathrm{SiO}_{3}{ }^{2-}$ are $0 \%, 39 \%$, and $61 \%$, respectively. When $\mathrm{pH}=13.0$, these coefficients are $0 \%, 6 \%$, and $94 \%$, respectively, [29]. This trend indicated that silicon exists only in the form of $\mathrm{SiO}_{3}{ }^{2-}$ that is beneficial to the formation of CSH.

3.2. Complexation between $\mathrm{CaO}$ and $P E G_{2000}$. The reaction mechanism between $\mathrm{CaO}$ and $\mathrm{PEG}_{2000}$ was revealed via FTIR analysis. Figures 1(a) and 1(b) show the FT-IR spectra of neat $\mathrm{CaO}$ and $\mathrm{CaO} / \mathrm{PEG}_{2000}$ composites, respectively. As shown in Figure 1(a), a broad and sharp peak at 1402 $1546 \mathrm{~cm}^{-1}$ and $870 \mathrm{~cm}^{-1}$ can be attributed to the characteristic peak of $\mathrm{CaO}$. The stretching vibration band of $\mathrm{C}-\mathrm{O}-\mathrm{C}$ at $1090 \mathrm{~cm}^{-1}$ and the characteristic absorption band occurred at about $2270 \mathrm{~cm}^{-1}$ due to a bent oscillation peak of $\mathrm{C}-\mathrm{H}$ bond in Figure 1(b) can be assigned to bands of $\mathrm{PEG}_{2000}$, and the absorption peak of $\mathrm{C}-\mathrm{O}-\mathrm{C}$ moves to a low band. This phenomenon indicated that the asymmetric stretching vibration frequency of $\mathrm{C}-\mathrm{O}-\mathrm{C}$ group of $\mathrm{PEG}_{2000}$ decreased due to the effect of $\mathrm{Ca}^{2+}$. Furthermore, this result demonstrated that $\mathrm{Ca}^{2+}$ reacted with oxygen atom in PEG molecule to form complexation structure; that is, $\mathrm{CaO}$ and $\mathrm{PEG}_{2000}$ existed together in the form of complex.

\subsection{The Porosity Formation Mechanism of CSH}

3.3.1. Morphological Structure. The surface morphology of $\mathrm{CSH}(\mathrm{CaO})$ and $\mathrm{CSH}\left(\mathrm{CaO} / \mathrm{PEG}_{2000}\right)$ was examined by FESEM, as shown in Figures 2(a) and 2(b). It can be seen that $\mathrm{CSH}(\mathrm{CaO})$ possessed a dense surface and compact structure (Figure 2(a)). In contrast, pore size of $\mathrm{CSH}\left(\mathrm{CaO} / \mathrm{PEG}_{2000}\right)$ tended to be larger (Figure 2(b)). The morphological structure of $\mathrm{CSH}(\mathrm{CaO})$ and $\mathrm{CSH}\left(\mathrm{CaO} / \mathrm{PEG}_{2000}\right)$ was further examined by TEM, as shown in Figures 2(c) and 2(d). The TEM image shows that the surface of $\mathrm{CSH}(\mathrm{CaO})$ was compact (Figure 2(c)) consistent with the FESEM observation. In contrast, $\mathrm{CSH}\left(\mathrm{CaO} / \mathrm{PEG}_{2000}\right)$ possesses hollow microspheres due to the absence of the hardly dissolved intermediates (Figure 2(d)).

3.3.2. Specific Surface Area and Pore Structure. The $S_{\mathrm{BET}}$ and pore structure of the as-prepared samples were investigated by adsorption-desorption measurements. As shown in Table 2, the $S_{\mathrm{BET}}$ of $\mathrm{CSH}\left(\mathrm{CaO} / \mathrm{PEG}_{2000}\right)$ increased to $133 \mathrm{~m}^{2} / \mathrm{g}$ compared to $\mathrm{CSH}(\mathrm{CaO})\left(62 \mathrm{~m}^{2} / \mathrm{g}\right)$. In comparison to $\mathrm{CSH}(\mathrm{CaO})\left(0.16 \mathrm{~cm}^{3} / \mathrm{g}\right)$, the pore volume of $\mathrm{CSH}$ $\left(\mathrm{CaO} / \mathrm{PEG}_{2000}\right)$ increased to $0.36 \mathrm{~cm}^{3} / \mathrm{g}$.

Figure 3(a) shows the $\mathrm{N}_{2}$ adsorption-desorption isotherms of the CSH samples. According to the BrunauerDeming-Deming-Teller (BDDT) classification, the majority

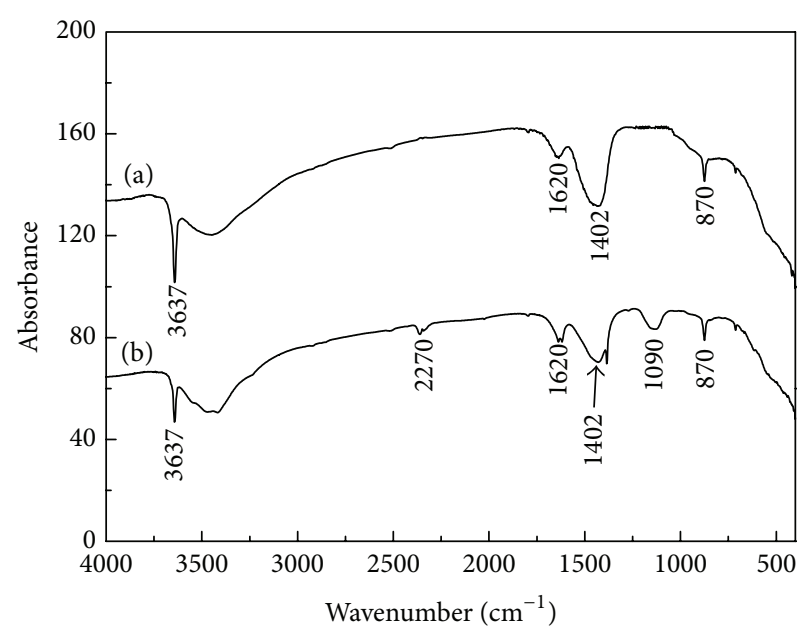

Figure 1: FT-IR spectra of $\mathrm{CaO}$ (a) and $\mathrm{CaO} / \mathrm{PEG}_{2000}$ composites (b).

TABLE 2: Specific BET surface areas and pore parameters of $\mathrm{CSH}$ samples.

\begin{tabular}{lccc}
\hline CSH samples & $\begin{array}{c}\text { Total volume } \\
\left(\mathrm{cm}^{3} / \mathrm{g}\right)\end{array}$ & $\begin{array}{c}\text { Peak pore diameter } \\
(\mathrm{nm})\end{array}$ & $S_{\mathrm{BET}}\left(\mathrm{m}^{2} / \mathrm{g}\right)$ \\
\hline $\mathrm{CSH}(\mathrm{CaO})$ & 0.16 & 13.57 & 62 \\
$\mathrm{CSH}$ & 0.36 & 5.8 & 133 \\
$\left(\mathrm{CaO} / \mathrm{PEG}_{2000}\right)$ & & & 133 \\
\hline
\end{tabular}

of physisorption isotherms can be grouped into six types. The isotherms of all the samples belonged to type IV, including the pore-size distributions in the mesoporous regions [30]. The shapes of hysteresis loops were of the type $\mathrm{H} 3$, which was associated with mesopores formed due to aggregation of plates-like particles [31].

Figure 3(b) shows the corresponding PSD of the samples. For the CSH $(\mathrm{CaO})$, the PSD curve is bimodal with smaller $(\sim 2.54 \mathrm{~nm})$ and larger $(\sim 45.42 \mathrm{~nm})$ mesopores. For $\mathrm{CSH}$ $\left(\mathrm{CaO} / \mathrm{PEG}_{2000}\right)$, the PSD curve exhibits small $(\sim 6.52 \mathrm{~nm})$ mesopores. The small mesopores and larger ones came from the aggregation of primary particles and secondary particles, respectively. This result was consistent with the result of $\mathrm{N}_{2}$ adsorption-desorption isotherms. A large number of small mesopores contribute to the large $S_{\mathrm{BET}}$.

3.3.3. Phase Structure. Figure 4 shows the XRD patterns of $\mathrm{CSH}(\mathrm{CaO})$ and $\mathrm{CSH}\left(\mathrm{CaO} / \mathrm{PEG}_{2000}\right)$. Multiple phases, such as Jennite (PDF card 18-1206, chemical formula $\mathrm{Ca}_{9} \mathrm{Si}_{6} \mathrm{O}_{18}(\mathrm{OH})_{6} \cdot 8 \mathrm{H}_{2} \mathrm{O}$ ), xonotlite (PDF card 23-0125, chemical formula $\mathrm{Ca}_{6} \mathrm{Si}_{6} \mathrm{O}_{17}(\mathrm{OH})_{2}$ ), and $\mathrm{Ca}_{3} \mathrm{Si}_{2} \mathrm{O}_{7}$ (PDF card 11-0317), appear in the XRD pattern of Figure 4(a). By comparison, the phase of $\mathrm{CSH}\left(\mathrm{CaO} / \mathrm{PEG}_{2000}\right)$ was only Jennite (Figure 4(b)). Combined with the above analysis, the as-prepared $\mathrm{CSH}\left(\mathrm{CaO} / \mathrm{PEG}_{2000}\right)$ (i.e., Jennite), without intermediates, exhibited large $S_{\mathrm{BET}}$ and porous structure.

The porosity formation mechanism can be revealed as follows: (1) during the heating process, $\mathrm{SiO}_{3}{ }^{2-}$ was released from $\mathrm{SiO}_{2}$ materials due to the increased $\mathrm{pH}$ value (13.0), and $\mathrm{Ca}^{2+}$ cannot be released from $\mathrm{CaO} / \mathrm{PEG}_{2000}$ composites due to 


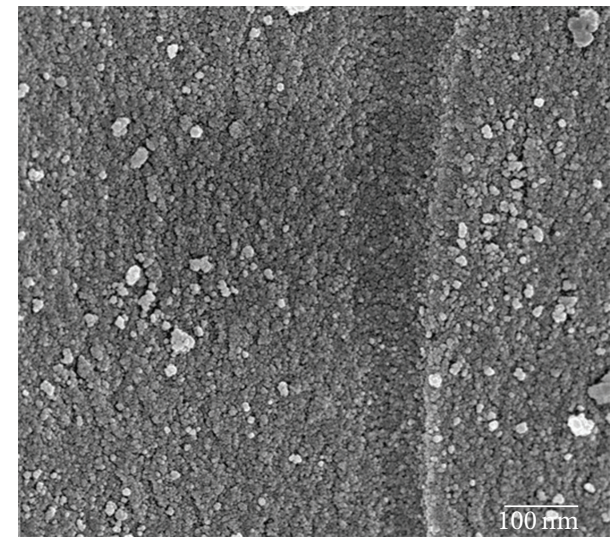

(a)

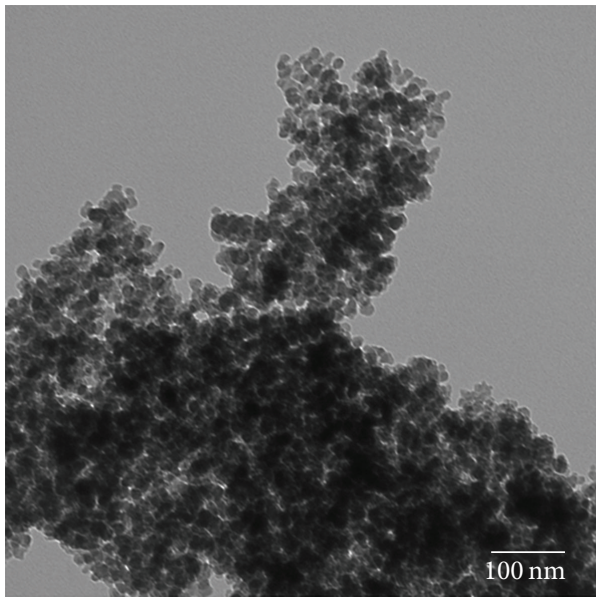

(c)

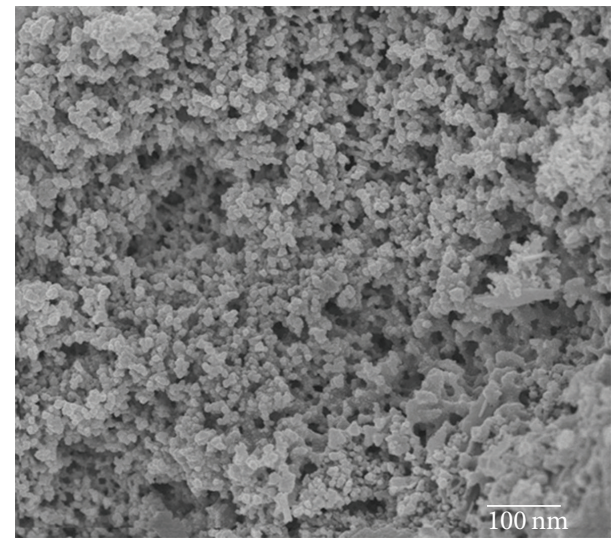

(b)

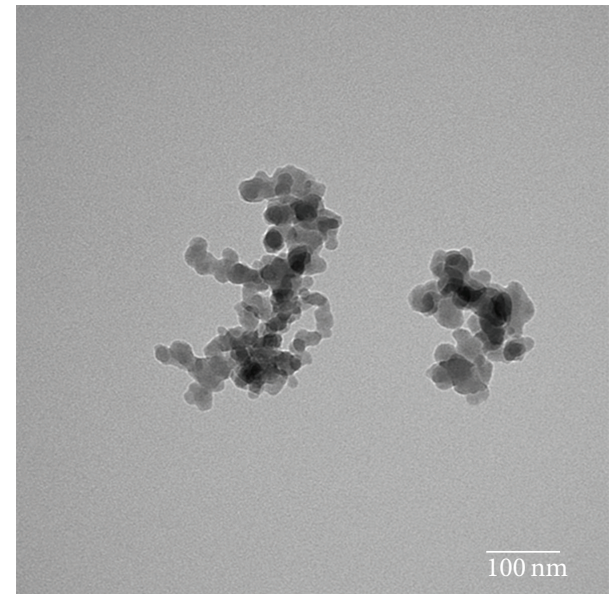

(d)

Figure 2: FESEM photographs of $\mathrm{CSH}(\mathrm{CaO})(\mathrm{a})$ and $\mathrm{CSH}\left(\mathrm{CaO} / \mathrm{PEG}_{2000}\right)(\mathrm{b}) ;$ TEM images of $\mathrm{CSH}(\mathrm{CaO})(\mathrm{c})$ and $\mathrm{CSH}\left(\mathrm{CaO} / \mathrm{PEG}_{2000}\right)(\mathrm{d})$.

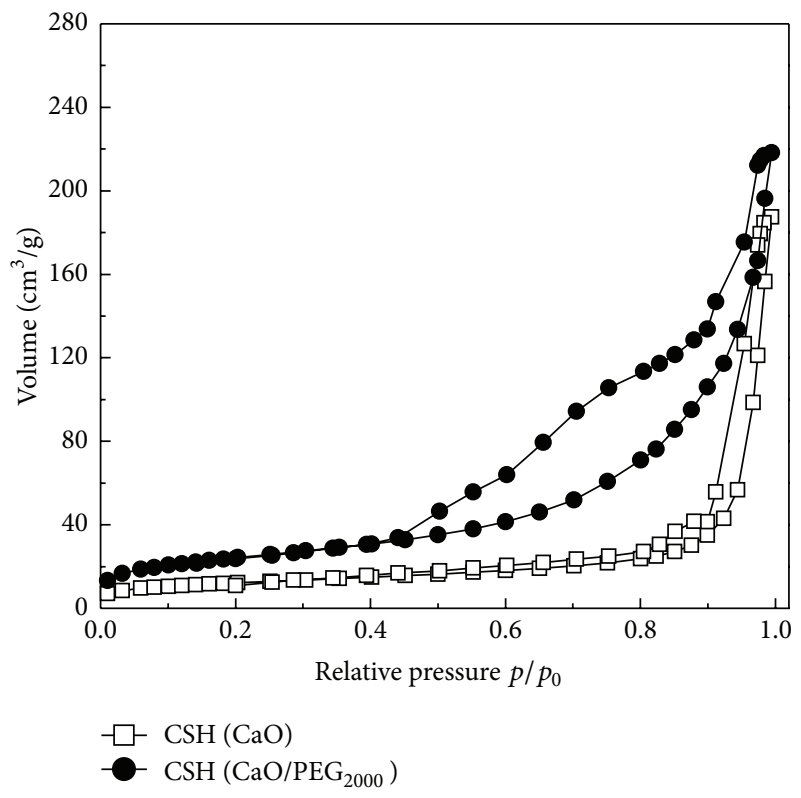

(a)

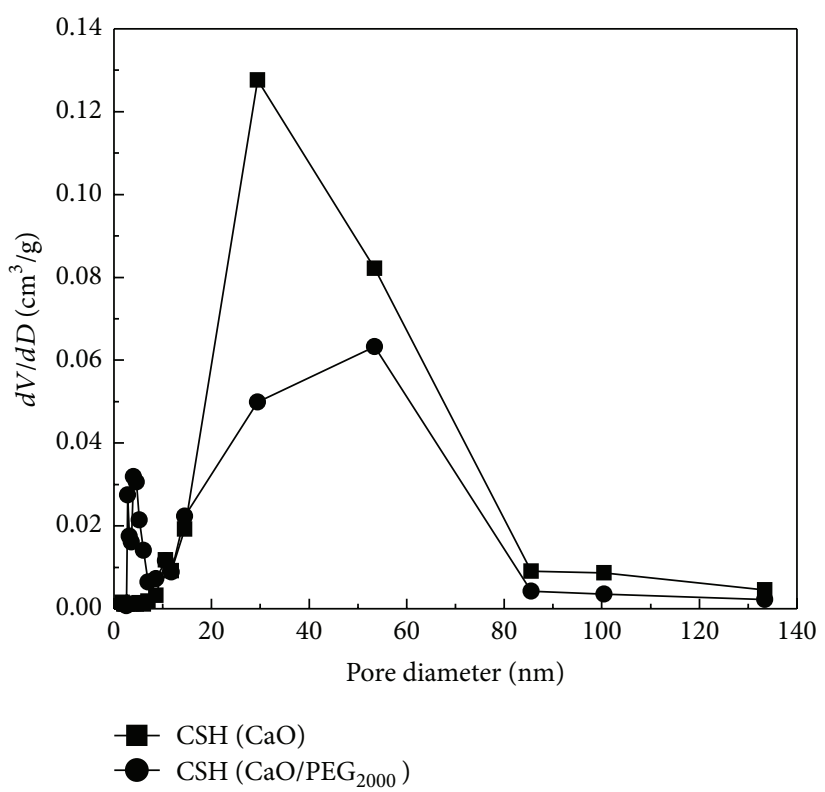

(b)

FIGURE 3: $\mathrm{N}_{2}$ adsorption-desorption isotherms (a) and pore-size distribution curves (b) of the as-prepared CSH samples. 


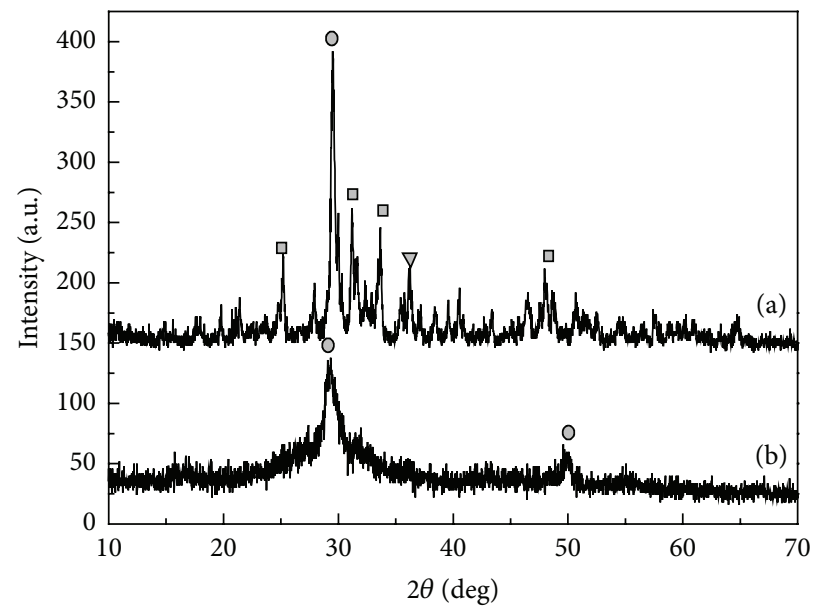

$$
\begin{aligned}
& \text { ○ Jennite } \\
& \square \mathrm{Ca}_{3} \mathrm{Si}_{2} \mathrm{O}_{7} \\
& \nabla \text { Xonotlite }
\end{aligned}
$$

Figure 4: XRD patterns of CSH $(\mathrm{CaO})(\mathrm{a})$ and $\mathrm{CSH}\left(\mathrm{CaO} / \mathrm{PEG}_{2000}\right)(\mathrm{b})$.

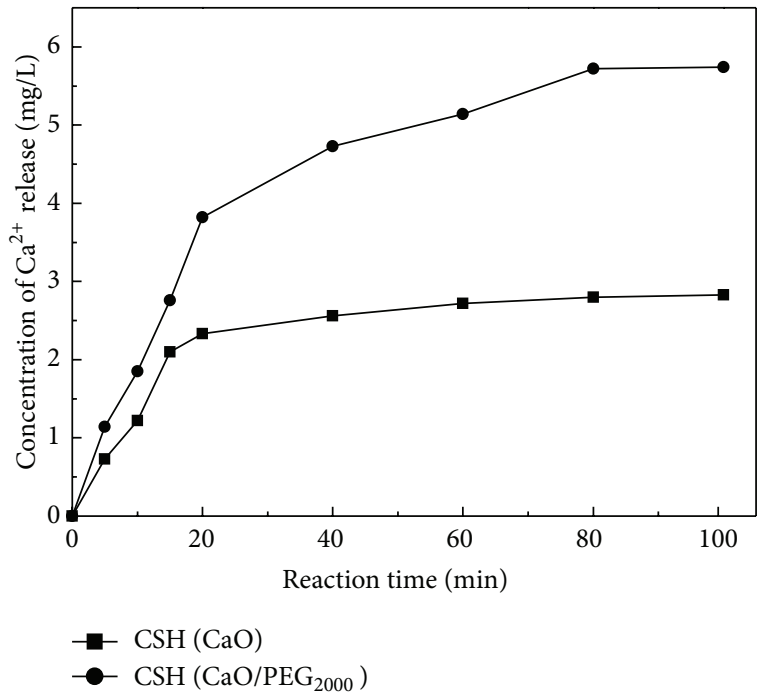

(a)

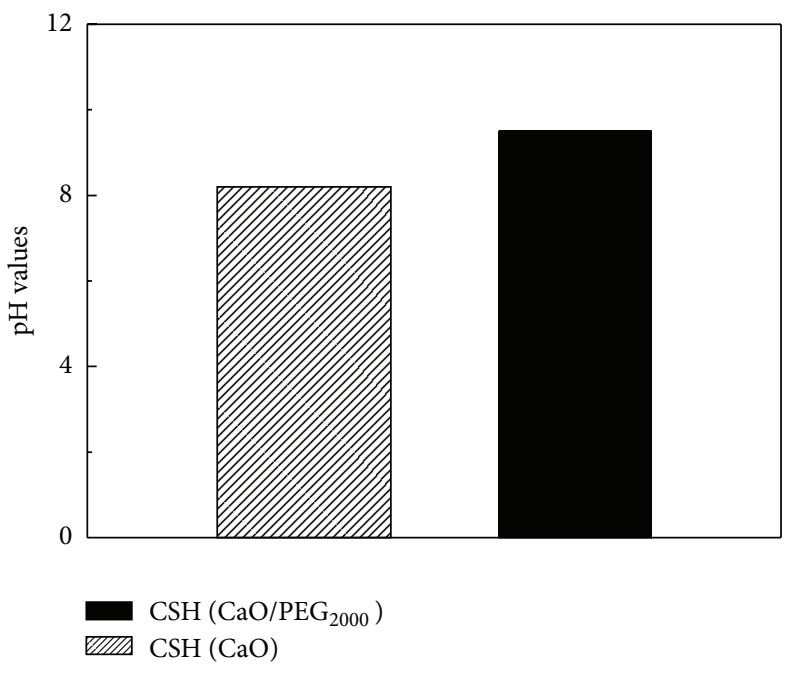

(b)

FIGURE 5: Concentration of $\mathrm{Ca}^{2+}$ released from CSH samples (a) and $\mathrm{pH}$ in deionized water kept by CSH samples (b).

the coating of $\mathrm{PEG}_{2000}$ below the hydrothermal temperature $\left(170^{\circ} \mathrm{C}\right)$; (2) when the hydrothermal temperature reached to a proper condition $\left(170^{\circ} \mathrm{C}\right)$, the molecular chain broke between $\mathrm{CaO}$ and $\mathrm{PEG}_{2000}$. At this time, $\mathrm{Ca}^{2+}$ released from $\mathrm{CaO} / \mathrm{PEG}_{2000}$ composites and reacted with $\mathrm{SiO}_{3}{ }^{2-}$ quickly to form $\mathrm{CSH}\left(\mathrm{CaO} / \mathrm{PEG}_{2000}\right)$. To the synthesis of $\mathrm{CSH}(\mathrm{CaO})$, massive $\mathrm{Ca}^{2+}$ was released from neat $\mathrm{CaO}$ materials during the heating process before the hydrothermal temperature reached to $170^{\circ} \mathrm{C}$, leading to formation of abundant hardly dissolved intermediates. By comparison, the new synthesis method herein avoided the formation of the hard dissolve intermediates.
3.4. The Enhanced Solubility of CSH. Figure 5 shows the variations of concentration of $\mathrm{Ca}^{2+}$ and $\mathrm{OH}^{-}$released from the as-synthesized $\mathrm{CSH}$ samples and $\mathrm{pH}$-values in deionized water. According to Figure 5(a), $\mathrm{CSH}\left(\mathrm{CaO} / \mathrm{PEG}_{2000}\right)$ releases more $\mathrm{Ca}^{2+}$ than $\mathrm{CSH}(\mathrm{CaO})$. Compared with the $\mathrm{CSH}(\mathrm{CaO})$ $(2.83 \mathrm{mg} / \mathrm{L})$, the concentration of $\mathrm{Ca}^{2+}$ was released from $\mathrm{CSH}\left(\mathrm{CaO} / \mathrm{PEG}_{2000}\right)$ and increased to $5.74 \mathrm{mg} / \mathrm{L}$. Figure 5(b) shows that the $\mathrm{pH}$ value of the solution can be kept at 9.5 by $\mathrm{CSH}\left(\mathrm{CaO} / \mathrm{PEG}_{2000}\right)$; however, $\mathrm{CSH}(\mathrm{CaO})$ can only maintain the $\mathrm{pH}$ value at 8.2. The as-prepared $\mathrm{CSH}\left(\mathrm{CaO} / \mathrm{PEG}_{2000}\right)$ with porous structure exhibited enhanced release capability of $\mathrm{Ca}^{2+}$ and $\mathrm{OH}^{-}$. 
3.5. The Enhanced Phosphate Recovery Property of CSH. The phosphate content of the product recovered by $\mathrm{CSH}$ $\left(\mathrm{CaO} / \mathrm{PEG}_{2000}\right)$ increased to $117.6 \mathrm{mg} / \mathrm{g}$, compared with $\mathrm{CSH}$ $(\mathrm{CaO})(84.5 \mathrm{mg} / \mathrm{g})$. This result indicated that the as-prepared porous $\mathrm{CSH}$, without the hardly dissolved intermediates, exhibited highly enhanced phosphate recovery property. Meanwhile, the recovered phosphate products, due to their abundant phosphate content, can be reused as phosphate rock or phosphate fertilizer.

\section{Conclusion}

Porous CSH was prepared based on the $\mathrm{CaO} / \mathrm{PEG}_{2000}$ composites as the calcium materials; $\mathrm{Ca}^{2+}$ could not sustain release from $\mathrm{CaO} / \mathrm{PEG}_{2000}$ and reacted with $\mathrm{SiO}_{3}{ }^{2-}$ caused by silica to form $\mathrm{CSH}$ until the hydrothermal temperature reached to $170^{\circ} \mathrm{C}$, avoiding the formation of hardly dissolved intermediates compared with previously reported synthesis methods. The as-prepared CSH, due to the large specific surface areas, exhibited excellent release capability of $\mathrm{Ca}^{2+}$ and $\mathrm{OH}^{-}$. Thus, the phosphate recovery property of $\mathrm{CSH}$ enhanced. The recovered phosphate products, due to their abundant phosphate content, can be reused in industry and agriculture instead of phosphate rock. Therefore, the asprepared porous material has potential application value in recovering phosphate from wastewater to solve the environmental problems caused by the shortage of phosphate resource.

\section{Conflict of Interests}

The authors declare that there is no conflict of interests regarding the publication of this paper.

\section{References}

[1] W. Cai, B. G. Zhang, Y. X. Jin et al., "Behavior of total phosphorus removal in an intelligent controlled sequencing batch biofilm reactor for municipal wastewater treatment," Bioresource Technology, vol. 132, pp. 190-196, 2013.

[2] B. M. Spears, S. Meis, A. Anderson, and M. Kellou, "Comparison of phosphorus $(\mathrm{P})$ removal properties of materials proposed for the control of sediment p release in UK lakes," Science of the Total Environment, vol. 442, pp. 103-110, 2013.

[3] D. Seyhan, "Country-scale phosphorus balancing as a base for resources conservation," Resources, Conservation and Recycling, vol. 53, no. 12, pp. 698-709, 2009.

[4] D. Cordell, J.-O. Drangert, and S. White, "The story of phosphorus: global food security and food for thought," Global Environmental Change, vol. 19, no. 2, pp. 292-305, 2009.

[5] C. J. Dawson and J. Hilton, "Fertiliser availability in a resourcelimited world: production and recycling of nitrogen and phosphorus," Food Policy, vol. 36, supplement 1, pp. S14-S22, 2011.

[6] S. Petzet, B. Peplinski, and P. Cornel, "On wet chemical phosphorus recovery from sewage sludge ash by acidic or alkaline leaching and an optimized combination of both," Water Research, vol. 46, no. 12, pp. 3769-3780, 2012.

[7] H. Kodera, M. Hatamoto, K. Abe, T. Kindaichi, N. Ozaki, and A. Ohashi, "Phosphate recovery as concentrated solution from treated wastewater by a PAO-enriched biofilm reactor," Water Research, vol. 47, no. 6, pp. 2025-2032, 2013.

[8] Z. Bradford-Hartke, P. Lant, and G. Leslie, "Phosphorus recovery from centralised municipal water recycling plants," Chemical Engineering Research and Design, vol. 90, no. 1, pp. 78-85, 2012.

[9] K. Okano, M. Uemoto, J. Kagami et al., "Novel technique for phosphorus recovery from aqueous solutions using amorphous calcium silicate hydrates (A-CSHs)," Water Research, vol. 47, no. 7, pp. 2251-2259, 2013.

[10] X. Cong and R. J. Kirkpatrick, " ${ }^{29}$ Si and ${ }^{17} \mathrm{O}$ NMR investigation of the structure of some crystalline calcium silica hydrates," Advanced Cement Based Materials, vol. 3, no. 3-4, pp. 133-143, 1996.

[11] H. Maeda and E. H. Ishida, "Hydrothermal preparation of diatomaceous earth combined with calcium silicate hydrate gels," Journal of Hazardous Materials, vol. 185, no. 2-3, pp. 858861, 2011.

[12] Z.-L. Ye, S.-H. Chen, S.-M. Wang et al., "Phosphorus recovery from synthetic swine wastewater by chemical precipitation using response surface methodology," Journal of Hazardous Materials, vol. 176, no. 1-3, pp. 1083-1088, 2010.

[13] J. J. Chen, J. J. Thomas, H. F. W. Taylor, and H. M. Jennings, "Solubility and structure of calcium silicate hydrate," Cement and Concrete Research, vol. 34, no. 9, pp. 1499-1519, 2004.

[14] C. Barca, C. Gérente, D. Meyer, F. Chazarenc, and Y. Andrès, "Phosphate removal from synthetic and real wastewater using steel slags produced in Europe," Water Research, vol. 46, no. 7, pp. 2376-2384, 2012.

[15] P. Q. Franco, C. F. C. João, J. C. Silva, and J. P. Borges, "Electrospun hydroxyapatite fibers from a simple sol-gel system," Materials Letters, vol. 67, no. 1, pp. 233-236, 2012.

[16] E. Vasile, L. M. Popescu, R. M. Piticescu, A. Burlacu, and T. Buruiana, "Physico-chemical and biocompatible properties of hydroxyapatite based composites prepared by an innovative synthesis route," Materials Letters, vol. 79, pp. 85-88, 2012.

[17] S. Santhosh and S. B. Prabu, "Thermal stability of nano hydroxyapatite synthesized from sea shells through wet chemical synthesis," Materials Letters, vol. 97, pp. 121-124, 2013.

[18] W. Guan, F. Y. Ji, Q. K. Chen, P. Yan, and W. W. Zhou, "Influence of hydrothermal temperature on phosphorus recovery efficiency of porous calcium silicate hydrate," Journal of Nanomaterials, vol. 2013, Article ID 451984, 6 pages, 2013.

[19] W. Guan, F. Y. Ji, Q. K. Chen, P. Yan, and Q. Zhang, "Preparation and phosphorus recovery performance of porous calciumsilicate-hydrate," Ceramics International, vol. 39, no. 2, pp. 13851391, 2013.

[20] X.-L. Zhao and M. Saigusa, "Fractionation and solubility of cadmium in paddy soils amended with porous hydrated calcium silicate," Journal of Environmental Sciences, vol. 19, no. 3, pp. 343-347, 2007.

[21] L. Nicoleau, "Accelerated growth of calcium silicate hydrates: experiments and simulations," Cement and Concrete Research, vol. 41, no. 12, pp. 1339-1348, 2011.

[22] S. Shaw, S. M. Clark, and C. M. B. Henderson, "Hydrothermal formation of the calcium silicate hydrates, tobermorite $\left(\mathrm{Ca}_{5} \mathrm{Si}_{6} \mathrm{O}_{16}(\mathrm{OH})_{2} \cdot 4 \mathrm{H}_{2} \mathrm{O}\right)$ and xonotlite $\left(\mathrm{Ca}_{6} \mathrm{Si}_{6} \mathrm{O}_{17}(\mathrm{OH})_{2}\right)$ : an in situ synchrotron study," Chemical Geology, vol. 167, no. 1-2, pp. 129-140, 2000.

[23] D. Sugiyama and T. Fujita, "A thermodynamic model of dissolution and precipitation of calcium silicate hydrates," Cement and Concrete Research, vol. 36, no. 2, pp. 227-237, 2006. 
[24] A. A. P. Mansur and H. S. Mansur, "Preparation, characterization and cytocompatibility of bioactive coatings on porous calcium-silicate-hydrate scaffolds," Materials Science and Engineering C, vol. 30, no. 2, pp. 288-294, 2010.

[25] C. Noiriel, L. Luquot, B. Madé, L. Raimbault, P. Gouze, and J. van der Lee, "Changes in reactive surface area during limestone dissolution: an experimental and modelling study," Chemical Geology, vol. 265, no. 1-2, pp. 160-170, 2009.

[26] H. Yang, L. Feng, C. Wang, W. Zhao, and X. Li, "Confinement effect of $\mathrm{SiO}_{2}$ framework on phase change of PEG in shapestabilized PEG/SiO $\mathrm{S}_{2}$ composites," European Polymer Journal, vol. 48, no. 4, pp. 803-810, 2012.

[27] Q. Guo and T. Wang, "Influence of $\mathrm{SiO}_{2}$ pore structure on phase change enthalpy of shape-stabilized polyethylene glycol/silica composites," Journal of Material Science, vol. 48, no. 10, pp. 3716-3721, 2013.

[28] I. Y. Kim, G. Kawachi, K. Kikuta, S. B. Cho, M. Kamitakahara, and C. Ohtsuki, "Preparation of bioactive spherical particles in the $\mathrm{CaO}-\mathrm{SiO}_{2}$ system through sol-gel processing under coexistence of poly(ethylene glycol)," Journal of the European Ceramic Society, vol. 28, no. 8, pp. 1595-1602, 2008.

[29] X. Huang, D. L. Jiang, and S. H. Tan, "Hydrothermal synthesis of tobermorite fibers through calcium chelated complex," Journal of Inorganic Materials, vol. 18, no. 1, pp. 143-148, 2003 (Chinese).

[30] F. Dong, S. C. Lee, Z. Wu et al., "Rose-like monodisperse bismuth subcarbonate hierarchical hollow microspheres: onepot template-free fabrication and excellent visible light photocatalytic activity and photochemical stability for NO removal in indoor air," Journal of Hazardous Materials, vol. 195, pp. 346354, 2011.

[31] F. Dong, H. T. Liu, W. K. Ho, M. Fu, and Z. B. Wu, “ $\left(\mathrm{NH}_{4}\right)_{2} \mathrm{CO}_{3}$ mediated hydrothermal synthesis of $\mathrm{N}$-doped $(\mathrm{BiO})_{2} \mathrm{CO}_{3}$ hollow nanoplates microspheres as high-performance and durable visible light photocatalyst for air cleaning," Chemical Engineering Journal, vol. 214, pp. 198-207, 2013. 

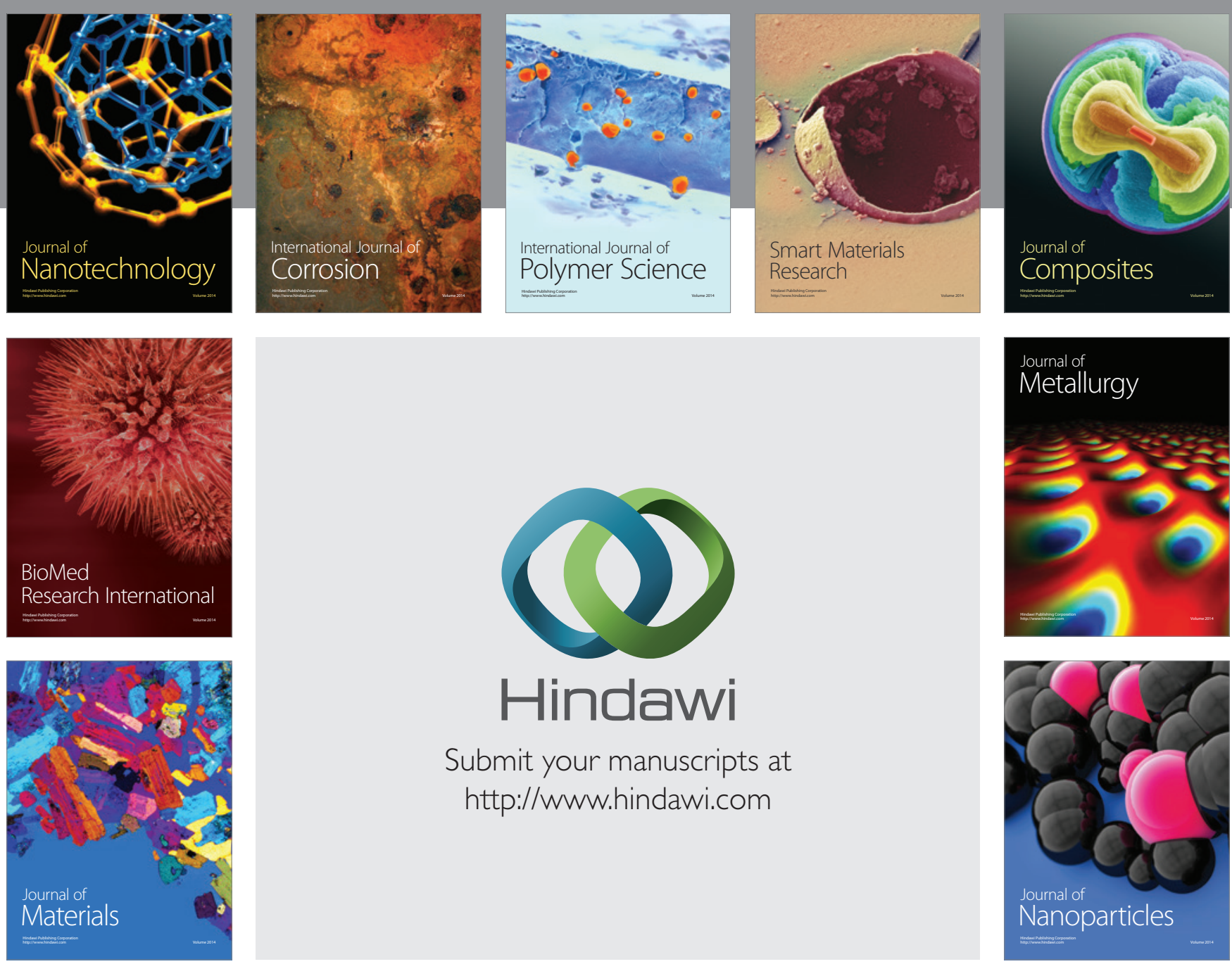

Submit your manuscripts at http://www.hindawi.com
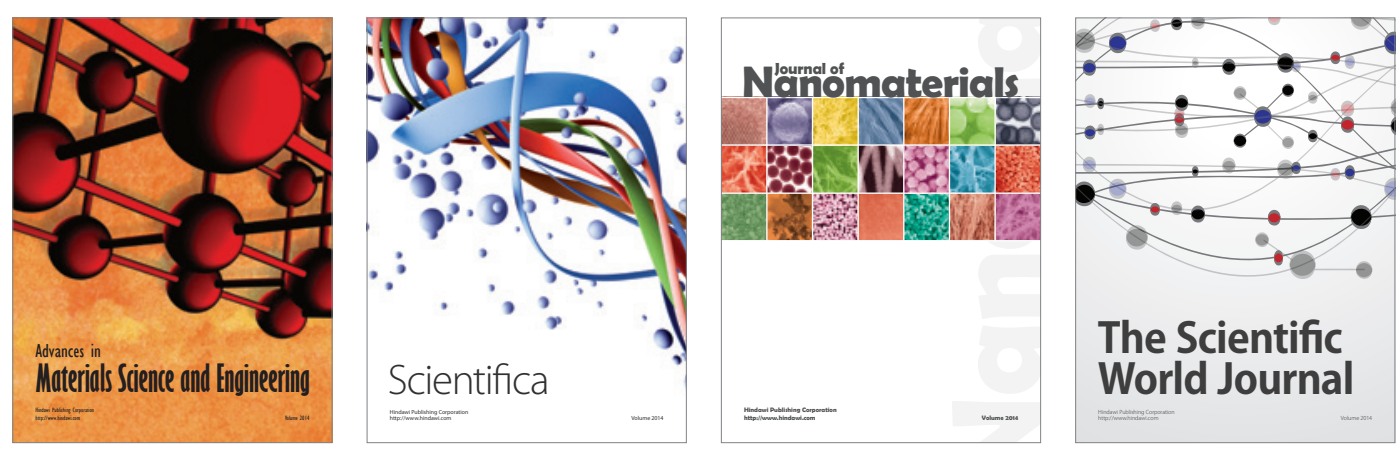

\section{The Scientific World Journal}
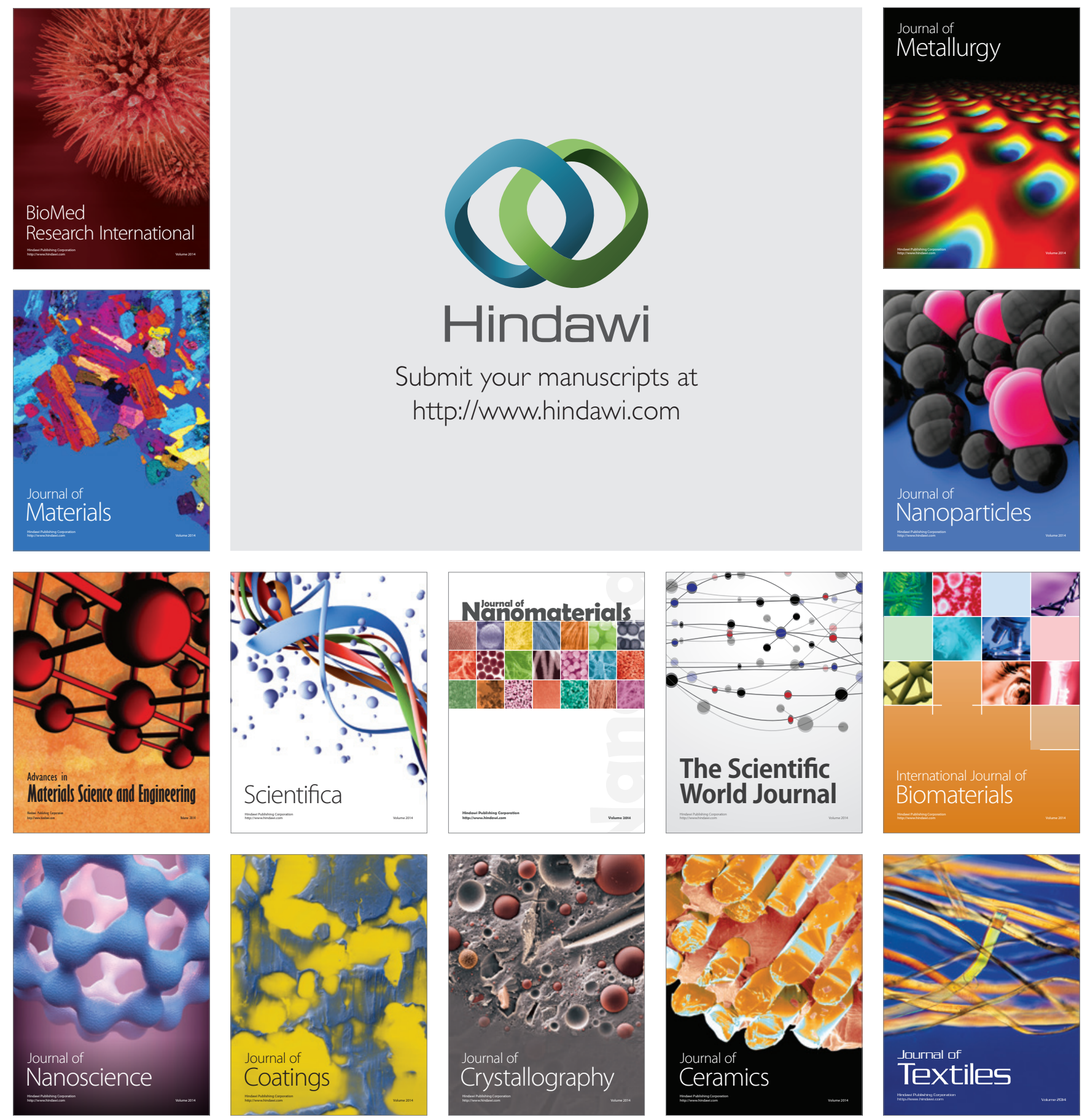